\title{
ЗАГОСТРЕННЯ ПРОТИРІЧ У ПІДГОТОВЦ УГОДИ ПРО АСОЦІАЦІЮ УКРАЇНИ 3 ЄС (ЛИПЕНЬ-ЖОВТЕНЬ 2013 р.)
}

Анотація: Розкривається поглиблення проблем навколо підписання Угоди про асоціацію України з Європейським Союзом. Детально відтворено збільшення економічного та дипломатичного тиску російської влади на Віктора Януковича з метою зірвати підписання угоди. Це включало в себе включення частини українських підприємств до «чорного списку» митниці РФ і прямий шантаж російської верхівки.

На основі даних періодики реконструйовано процес переговорів між украӥнською владою та представниками Європарламенту щодо умов звільнення Юлії Тимошенко. Виокремлено основні плани вирішення проблеми Ю. Тимошенко: часткове помилування (зменшення строку покарання, виплата шттрафу та позбавлення громадянських прав на три роки) та лікування за кордоном (зміна законодавства з метою зробити легальним залишення країни в'язнем у випадку необхідності лікування у зарубіжних закладах). Підкреслено, що В. Янукович віддавав перевагу першому варіанту, що гарантував неучасть Тимошенко у президентських виборах 2015 р. Однак у підсумку він використав проблему ув'язнення найбільш впливового опозищійного лідера задля затягування переговорів з ЄC, без бажання продовжувати рух до Європи на фоні зростання російського тиску та відвертих погроз керівниитва РФ.

Проаналізовано роль європейських політиків у спробах вирішити переговорну кризу, зокрема ролі Пета Кокса, Александра Кваснєвського, Радослава Сікорського та Карла Більдта. Відтворено позицію Юлії Тимошенко та ї̈ оточення щодо планів звільнення з ув'язнення: намір боротися за відновленні громадянських прав у випадку часткового помилування, згода відкласти вирішення проблеми на більш пізній термін в обмін підписання угоди про асоціацію з ЕС. Доведено, що режим Януковича обрав шлях зближення з РФ як спосіб уникнути поразки на президентських виборах 2015 р. та через страх внаслідок погроз російської верхівки.

Ключові слова: Віктор Янукович, асоціація України з ЕС, Юлія Тимошенко, євроінтеграція, Пет Кокс, Алєксандр Кваснєвський

2010-2014 роки стали кульмінацією існування в Україні гібридного режиму, що постав на руїнах радянської економічної, соціальної, політичної та духовної систем внаслідок «незавершеної революції» 1991 р. Віктор Янукович не був винахідником ані неформальних кланів, ані всеосяжної політичної корупції, ані потужних фінансовопромислових груп. Однак саме за його правління ці явища в українському суспільстві досягли максимального розмаху за роки незалежності. Внутрішні суперечності створеного четвертим Президентом режиму наприкінці його правління стали настільки гострими, що цілком закономірно призвели до його краху внаслідок Революції Гідності. Наріжним каменем у цьому процесі стало питання Асоціації України та ЄС. Воно перетворилося на

\footnotetext{
" Денисенко Вадим Ігорович - кандидат філологічних наук, докторант Запорізького національного університе-
} Ty; ORCID: https://orcid.org/0000-0003-4317-2884 ; e-mail: uifuture@gmail.com 
«лакмусовий папірець», що змусив четвертого Президента чітко розкрити пріоритети функціонування вибудованої ним владної вертикалі. Тож аналіз історії України 20102014 pp. є неможливим без урахування контексту відносин з ЄС, зокрема процесу погодження та підготовки асоціації.

Наявні наукові розвідки представляють процес підготовки до укладання угоди вкрай схематично й узагальнено. У праці О. Серікової розкрито економічний вимір укладення угоди 1 . Низка аналітичних матеріалів «мозкових центрів» (Національний інститут стратегічних досліджень, Фонд імені Конрада Аденауера, Центра імені Разумкова) звертають увагу на вплив асоціації на реформування українського суспільства та юридичні аспекти їі імплементації². Між тим, вкрай важливо розуміти деталі перемовин між В. Януковичем та функціонерами ЄС для відтворення подальшої логіки кризи та зникнення системи влади, вибудуваної четвертим українським Президентом.

Наближення моменту підписання Угоди про Асоціацію з ЄС посилило політичний i економічний тиск на Київ з боку Кремля. У липні близько 40 великих українських підприємств потрапили до «чорного переліку» російської митниці. Вона почала ретельно перевіряти їхні вантажі, затягуючи час поставки товарів замовникам ${ }^{3}$.

У середині серпня радник президента РФ Сергій Глазьєв прямо пов'язав ці дії РФ 3 євроінтеграційними планами України. «Справа в тому, що російська митна служба проводила профілактичні заходи, пов'язані з підготовкою змін режиму митного адміністрування в разі, якщо Україна підпише Угоду про асоціацію з ЄС», - сказав він і попередив: «Ми про всяк випадок готуємося до посилення митного адміністрування, якщо раптом Україна здійснить цей самогубний крок». «На українському ринку з'явиться величезна кількість європейських, турецьких та інших товарів, які потім будуть перетікати до нас», розповів він ${ }^{4}$.

Аргументи С. Глазьєва спростував речник єврокомісара 3 питань торгівлі Джон Кленсі. Він звернув увагу на Угоду про Правила визначення країни походження товарів у Співдружності Незалежних Держав : згідно з цими Правилами, товари ЄС, які експортуватимуться в Україну через майбутню зону вільної торгівлі з ЄС, не зможуть претендувати на пільги при експорті з України до РФ. Таким чином, пояснив Д. Кленсі, створення Укра-

\footnotetext{
${ }^{1}$ Серікова О.М. Соціально-економічні наслідки угоди про асоціацію між Україною та ЄС для машинобудування // Економічний аналіз: зб. наук. праць / Тернопільський національний економічний університет; редкол.: О.В. Ярощук (голов. ред.) та ін. Тернопіль: Видавничо-поліграфічний центр Тернопільського національного економічного університету «Економічна думка», 2017. Том 27. № 4. С. 91-99.

${ }^{2}$ Угода про асоціацію між Україною та ЄС: перспективи підписання та можливості тимчасового застосування. Аналітична записка (2012 p.). URL: http://old2.niss.gov.ua/articles/911/; Угода про асоціацію Україна-ЄC: дороговказ реформ. Київ: Фонд К. Аденауера, 2012. 53 с.; Малик Я. Угода про асоціацію Україна - ЄС як шлях реформування українського суспільства // Демократичне врядування. Науковий вісник. 2013. Вип. 11. URL: http://lvivacademy.com/vidavnitstvo_1/visnik11/fail/Malyk.pdf

${ }^{3}$ Половецький $M$. Росія розв'язала торговельну війну проти україни. URL: https://www.epravda.com.ua/publications/2013/08/12/389401/

${ }^{4}$ Росія готується посилити митний контроль у відповідь на зближення України і ЄС. Дзеркало тижня. 2013. 18 серпня. URL: https://dt.ua/ECONOMICS/rosiya-gotuyetsya-posiliti-mitniy-kontrol-u-vidpovid-nazblizhennya-ukrayini-i-yes-126953_html

${ }^{5}$ Угода про Правила визначення країни походження товарів у Співдружності Незалежних Держав. 2011 р. URL: https://zakon.rada.gov.ua/laws/show/997_m65
} 
їною зони вільної торгівлі з ЄС не може слугувати виправданням для посилення РФ митного режиму щодо України ${ }^{6}$.

Невдовзі у Кремля з'явилася інша версія, чому він погрожує Україні посиленням митного режиму. Цю версію озвучив сам Володимир Путін 22 серпня: «Якщо наші сусіди підуть на істотну лібералізацію митного режиму з ЄС, то на ринок України дійсно неминуче хлинуть товари, досить непогані за якістю і за ціною. Але це призведе до того, що вони будуть видавлювати з власне українського ринку товари саме українського виробництва. I тоді країнам Митного союзу доведеться подумати про захисні заходи» ${ }^{7}$. У подальшому Кремль об'єднав дві версії в одну: він хоче убезпечитися від напливу на ринок РФ як європейських, так і українських товарів.

Попри тиск з боку Кремля, Київ продовжував підготовку до Вільнюського саміту. 18 вересня Кабмін прийняв рішення «Про підготовку до підписання проекту Угоди про асоціацію між Україною, з однієї сторони, та Європейським Союзом і його державамичленами, з іншої сторони», яким схвалив проект Угоди про асоціацію і тим самим дав старт внутрішньодержавним процедурам підготовки документа до підписання на саміті у Вільнюсі ${ }^{8}$ Голова представництва ЄC в Україні Ян Томбінський на прес-конференції у Кабміні наголосив: «Це було одноголосно схвалено». Він нагадав, що з боку ЄС виконання цієї процедури також наближається до кінця. «Це дуже важливий і рішучий крок українського уряду», - наголосив Я. Томбінський ${ }^{9}$

Того ж дня відбулася зустріч Миколи Азарова з В. Януковичем. «Сьогодні головним питанням було, звичайно, розгляд урядом проекту Угоди, яку ми збираємося підписати у Вільнюсі, про асоціацію з Європейським Союзом. Президента цікавили можливі ризики і те, як уряд збирається попереджати ці ризики. Ми цю тему досить докладно обговорили», - повідомив Азаров після зустрічі ${ }^{10}$.

Після того Москва посилила свій шантаж. 23 вересня прем'єр-міністр РФ Дмитро Медведєв заявив, що для України у разі підписання нею Угоди про асоціацію з ЄС закінчиться «особливий режим, партнерський, який діяв досі» у торгівлі з РФ. «Так, ми будемо дружити, торгувати, але це буде торгівля така сама, як ми ї̈ ведемо 3 нашими іншими партнерами, - без будь-яких привілеїв, навпаки, можливо, навіть з обмеженнями. Хай спробують продати свою продукцію в Європу», - сказав він ${ }^{11}$.

При цьому він порадив Києву не ображатися на заходи, які РФ буде вживати для захисту свого ринку після підписання Україною угоди з ЄС. «Не треба ображатися на нас-

\footnotetext{
${ }^{6}$ Євросоюз засудив санкції Росії проти українських виробників. Дзеркало тижня. 2013. 20 серпня. URL: https://dt.ua/ECONOMICS/yevrosoyuz-zasudiv-sankciyi-rosiyi-proti-ukrayinskih-virobnikiv-127040_html

${ }^{7}$ Совещание о социально-экономическом развитии Ростовской области. 22 августа 2013 г. URL: http://kremlin.ru/events/president/news/19063

${ }^{8}$ Протокол №55 засідання Кабінету міністрів України від 18 вересня 2013 р. (копія) // Особистий архів B.I. Денисенка.

${ }^{9}$ Кабмін схвалив угоду із Європою. Украӥнська правда. 2013. 18 вересня. URL: https://www.pravda.com.ua/news/2013/09/18/6998172/

${ }^{10}$ Янукович обговорив з Азаровим асоціацію з ЄС і подальшу долю відносин з Росією. Дзеркало тижня. 2013. 18 вересня. URL: https://dt.ua/POLITICS/yanukovich-obgovoriv-z-azarovim-asociaciyu-z-yes-i-podalshu-dolyuvidnosin-z-rosiyeyu-128649_html

${ }^{11}$ Дмитрий Медведев встретился с членами Совета палаты Совета Федерации. URL: http://government.ru/news/5990/
} 
лідки, а вони будуть, - пригрозив Д. Медведєв. - Договір про асоціацію має частково набути чинності ще до ратифікації. Якісні товари з Європи прийдуть на ринок України, а звідти - до нас. Ми будемо використовувати всі можливості, які в нас є в межах СОТ, щодо українських та європейських товарів» ${ }^{12}$.

Утім, цей шантаж з боку Москви створював для В. Януковича не лише проблеми у сфері економіки, а й нові можливості у сфері євроінтеграції. ЄС почав розглядати Україну як жертву економічної агресії РФ та, як наслідок, шукав можливості допомогти Україні. Зокрема, міністр закордонних справ Литви Лінас Лінкявічюс (його країна тоді головувала в $E C$ і якраз готувалася до проведення Вільнюського саміту) повідомив, що 18 жовтня у Люксембурзі Рада ЄС з питань торгівлі назвала неприйнятним тиск РФ на країни Східного партнерства й у зв'язку з цим запропонувала «почати тимчасове застосування з Україною поглибленої та всеохоплюючої зони вільної торгівлі якомога швидше» ${ }^{13}$.

Водночас $Є C$ дедалі більше був схильний пробачати В. Януковичу негативні явища у внутрішній політиці, якщо він проявлятиме себе національним лідером, здатним чинити спротив тиску Кремля. І деякий час В. Янукович виглядав таким лідером.

Щоправда, це не звільнило його від вимоги розв'язати проблему Ю. Тимошенко. На той час обговорювалися різні варіанти, але компромісу досягнуто не було.

15 жовтня Пет Кокс і Александр Кваснєвський виступили з усним звітом про роботу очолюваної ними моніторингової місії Європарламенту на позачерговому засіданні Конференції президентів Європарламенту (це керівний орган Європарламенту, до складу якого входять президент Європарламенту і президенти політичних груп Європарламенту) у Брюсселі. Журналістам було представлено коротку письмову версію звіту ${ }^{14}$.

«Вирішення питань вибіркового правосуддя є однією з ключових вимог, визначених Радою Європейського Союзу у закордонних справах у грудні 2012 р. для підписання Угоди про асоціацію з Україною, - зазначається у документі. - Нам було доручено Європейським Парламентом розглянути питання про вибіркове правосуддя в Україні. Умови для підписання були встановлені Радою ЄC у закордонних справах, а не нашою місією. На нашу думку, ці умови, особливо щодо Юлії Тимошенко, ще залишаються невиконаними. Після 16 місяців і 22 місій ми дійшли висновку, що наразі необхідна подальша робота для забезпечення відповідності. У цьому контексті ми віримо, що ця місія повинна продовжувати свої зусилля для того, щоб сприяти реалізації взаємоприйнятного рішення до прийняття Радою Європейського Союзу рішення про можливе підписання Угоди про асоціацію» ${ }^{15}$.

Президент Європарламенту Мартін Шульц повідомив журналістам, що Конференція президентів Європарламенту продовжила мандат моніторингової місії до середини листопада. «Ми продовжимо місію, тому що мета - вирішення справи Тимошенко - не

\footnotetext{
${ }^{12}$ Медведєв: асоціація 3 EC завершить партнерський режим 3 Україною. URL: https://www.bbc.com/ukrainian/politics/2013/09/130923_medvedev_ukraine_problems_vc.

${ }^{13}$ ЄC форсує створення зони вільної торгівлі з Україною. Дзеркало тижня. 2013. 18 жовтня. URL: https://dt.ua/ECONOMICS/yes-forsuye-stvorennya-zoni-vilnoyi-torgivli-z-ukrayinoyu-130354_html.

${ }^{14}$ Текст доповіді місії Кокса-Кваснєвського у Брюсселі. Дзеркало тижня. 2013. 15 жовтня. URL: https://dt.ua/POLITICS/tekst-dopovidi-misiyi-koksa-kvasnyevskogo-u-bryusseli-130114_html.

${ }^{15}$ Cox-Kwasniewski mission report in the European Parliament. URL: https://www.kyivpost.com/article/opinion/oped/cox-and-kwasniewskis-mission-report-in-the-european-parliament-330544.html.
} 
досягнута, - зазначив А. Кваснєвський. - Ми обговорювали всі можливі сценарії, і ми близькі до знаходження реалістичного сценарію, який буде прийнятний для трьох сторін - ми говоримо про владу України, пані Тимошенко та Європейський Союз». М. Шульц повідомив, що звіт П. Кокса - А. Кваснєвського буде відправлений В. Януковичу і може стати «легальною основою» для знаходження рішення. «Все ще $є$ шанс досягти рішення. Якби не було шансу , ми б не продовжували місію», - заявив М. Шульц ${ }^{16}$.

Невдовзі депутат Європарламенту від Польщі Марек Сівець розкрив подробиці можливого компромісу. За його словами, в усному звіті на Конференції президентів Європарламенту 15 жовтня А. Кваснєвський озвучив такі умови звільнення Ю. Тимошенко, запропоновані українською владою: «рунтуючись на чинному українському законодавстві, президент здійснює часткове помилування Тимошенко. Часткове помилування означає скорочення її вироку з семи років на половину. Оскільки екс-прем'єр відсиділа вже більше половини скороченого строку, з'являться підстави для умовно-дострокового звільнення. Водночас Тимошенко повинна заплатити штраф у розмірі близько $\$ 200$ млн. і буде позбавлена громадянських прав на три роки ${ }^{17}$.

Ця інформація важлива для розуміння того, що було найважливішим для В. Януковича: він погоджувався випустити Ю. Тимошенко на волю (у той чи інший спосіб) за умови, що вона не зможе балотуватися на чергових президентських виборах у 2015 p. Звідси й вимога про позбавлення ії громадянських прав (мається на увазі право обіймати посади, у т. ч. виборні, у державній владі) на три роки.

На той момент ще не дали згоди на варіант часткового помилування опозиція та сама Ю. Тимошенко. Тому водночас пророблявся інший варіант: прийняти закон, який випустив би Ю. Тимошенко на лікування за кордон. 17 жовтня, перебуваючи у Донецьку, В. Янукович заявив: «Зараз політичними силами, представленими в парламенті, підготовлено законопроект, який дозволить вирішити це завдання. Сьогодні в Україні немає закону, який дозволив би Тимошенко виїхати за кордон. Як тільки це питання у парламенті буде вирішено, і у мене на стіл ляже цей закон, тоді буде питання до президента. Звичайно, якщо парламент прийме цей закон, я його підпишу» ${ }^{18}$. Певно, що такий закон влаштував би В. Януковича, знову ж таки, лише у разі, якби Ю. Тимошенко не поновлювалась у громадянських правах і не могла стати його конкуренткою на виборах у 2015 р.

Тобто фактично і за першим, і за другим варіантом Ю. Тимошенко мала одразу ж виїхати до Берліна для лікування у клініці «Charité». I далі залишатися у Німеччині та не брати участі в українському політичному житті принаймні три роки.

Однак подібні умови викликали спротив з боку ЄC і його найвпливовіших членів. 16 жовтня польська газета «Rzeczpospolita» розповіла, з посиланням на джерело в оточенні президента Польщі Броніслава Коморовського, що доля Угоди про асоціацію між Укра-

\footnotetext{
${ }^{16}$ Місію Кокса-Квасневського продовжено. украйнська правда. 2013. 15 жовтня. URL: https://www.pravda.com.ua/news/2013/10/15/7000049/

${ }^{17}$ Європейський депутат розповів, на яких умовах Янукович готовий відпустити Тимошенко. Дзеркало тижня. 2013. 16 жовтня. URL: https://dt.ua/POLITICS/yevropeyskiy-deputat-rozpoviv-na-yakih-umovah-yanukovichgotoviy-vidpustiti-timoshenko-130185_html

${ }^{18}$ Янукович пообіцяв підписати рішення Ради про можливість лікування Тимошенко за кордоном. Дзеркало тижня. 2013. 17 жовтня. URL: https://dt.ua/POLITICS/yanukovich-poobicyav-pidpisati-rishennya-radi-promozhlivist-likuvannya-timoshenko-za-kordonom-130234_html
} 
їною і ЄC залежить від «партії покеру» між В. Януковичем і канцлером Німеччини Ангелою Меркель. «3 одного боку, Янукович хоче вирішити проблему Тимошенко з найменшими витратами, побоюючись негативної реакції власного електорату і Юліної перемоги на президентських виборах через два роки, - розповіло джерело газети. - 3 іншого боку, Меркель відмовляється від підписання Угоди про асоціацію без звільнення Тимошенко, тому що дала таку публічну обіцянку і на це чекає німецька громадськість». Позиція Німеччини, зазначила газета, має вирішальне значення, тому що за нею послідує більшість країн Західної Європи. «У грі з Януковичем Меркель, здається, має сильніші карти. Результати Вільнюського саміту не загрожують її політичній кар'єрі. Результати переговорів з Брюсселем, однак, будуть вирішальними для політичного майбутнього українського президента», - припустила «Rzeczpospolita» ${ }^{19}$.

Визначальним став наступний тиждень, 21-27 жовтня. На його початку здавалося, що от-от буде досягнуто довгожданого компромісу. Очікувалося, що щаслива розв'язка відбудеться 24 жовтня. Натомість той день, з огляду на подальший розвиток подій, виявився точкою неповернення. І закінчився тиждень початком руху В. Януковича у зворотному напрямку - до РФ.

Спочатку зосередимося на подіях у ЄС. Того тижня українське питання розглядалося керівними органами ЄС тричі: спершу - на рівні міністрів закордонних справ, далі - у Європарламенті, а потім - на рівні перших осіб держав-членів ЄC.

21 жовтня у Люксембурзі відбулося засідання Ради ЄC у закордонних справах, на якому розглядалося питання виконання Україною критеріїв, необхідних для підписання Угоди про асоціацію. Після засідання міністр закордонних справ Польщі Радослав Сікорський визнав, що Київ продемонстрував успіхи у реалізації своїх зобов'язань перед ЄС. «У мене склалося серйозне враження, що шанс успіху саміту Східного партнерства у Вільнюсі є. Складається думка, що Україна досягла великого успіху, наганяючи в останні місяці і тижні щодо виконання реформ, яких вимагає ЄС. Насправді це - велика річ», - сказав Сiкорський. Він нагадав, що в Україні стосовно європейського порядку денного «вдалося налагодити співпрацю між урядом, президентом і опозицією».

«Але я б хотів застерегти українську владу щодо голосів кількох важливих членів EC, які говорять про те, що без вирішення справи Тимошенко їх країни, швидше за все, позитивного рішення не приймуть», - попередив польський міністр українську сторону. Такими країнами він назвав Нідерланди, Велику Британію та Швецію. Відповідаючи на запитання, коли саме ЄС має намір прийняти остаточне рішення у плані підписання Угоди про асоціацію, Сікорський сказав: «Ми могли б прийняти його сьогодні, якби всі умови були б виконані. I це викликає жаль. Я закликаю українські власті не недооцінювати складність прийняття рішень в $Є C$ - вони потребують часу. Часу залишається мало, а Україною так багато було зроблено, стільки всього позитивного, що було б трагедією, якщо Україна провалиться, перебуваючи в ста метрах до фінішу марафону». Він зазначив, що дата прийняття Євросоюзом остаточного рішення «все ще є предметом для дискусіі» ${ }^{20}$.

В. Янукович поставився до того засідання Ради ЄС з великою увагою. Він навіть від-

\footnotetext{
${ }^{19}$ Poker Merkel z Janukowyczem. URL: https://www.rp.pl/artykul/1057114-Poker-Merkel-z-Janukowyczem.html

${ }^{20}$ Три країни $\mathrm{C} \mathrm{не} \mathrm{підпишуть} \mathrm{угоду} \mathrm{з} \mathrm{Україною} \mathrm{без} \mathrm{вирішення} \mathrm{справи} \mathrm{Тимошенко.} \mathrm{Украӥнська} \mathrm{правда.} 2013$. 21 жовтня. URL: https://www.pravda.com.ua/news/2013/10/21/7000410/
} 
рядив до Люксембурга міністра зовнішніх справ Леоніда Кожару, щоб той дочекався завершення зборів своїх колег з країн ЄС і вивідав їхню думку.

Про підсумки засідання Л. Кожарі повідомив єврокомісар Штефан Фюле. За твердженням департаменту інформполітики M3C України, Ш.Фюле поінформував Л. Кожару, що міністри закордонних справ держав-членів ЄС відзначили прогрес, досягнутий українською стороною в реалізації критеріїв, визначених у висновках Ради ЄС 10 грудня 2012 р. У зв'язку з цим Ш. Фюле закликав українську владу вжити додаткових зусиль для забезпечення того, щоб 18 листопада Рада $\mathrm{EC} \mathrm{ухвалила} \mathrm{позитивне} \mathrm{рішення}$ щодо підписання Угоди про асоціацію. Л. Кожара запевнив єврокомісара у рішучій готовності керівництва України забезпечити подальший відчутний прогрес у виконанні всіх визначених завдань з метою підписання і початку тимчасового застосування Угоди про асоціацію ${ }^{21}$.

Зі свого боку, Рада ЄС приділила велику увагу тому, щоб донести свою думку безпосередньо до Януковича, і відрядила з цією місією до Києва міністрів закордонних справ Польщі та Швеції Радослава Сікорського та Карла Більдта. Вони 22 жовтня зустрілися 3 Януковичем i, схоже, під час розмови з ним виконували ролі «доброго та поганого поліцейських».

Після зустрічі з В. Януковичем Р. Сікорський розповів журналістам, що Київ повинен до 18 листопада вирішити всі проблемні питання для підписання Угоди про асоціацію з ЄС на саміті Східного партнерства у Вільнюсі. «Останній строк - це 18 листопада, коли відбудеться засідання Ради ЄC у закордонних справах. Часу для блефу у нас немає. Час активно діяти», - наголосив він. Яких саме дій Києва чекає Брюссель, конкретизував Більдт. Він заявив, що Брюссель не підпише Угоду про асоціацію без позитивного сигналу з боку моніторингової місії Європарламенту на чолі з Петом Коксом та Александром Кваснєвським, яка опікується долею Юлії Тимошенко. «Україна досягла великого прогресу у виконанні необхідних реформ. Залишилося одне питання, і рішення цього питання лежить у площині роботи місії Кокса і Кваснєвського. Без “зеленого світла" від них не буде “зеленого світла” від Європи... Годинник цокає, час іде, його залишилося мало», - сказав К. Більдт. На запитання журналіста про те, чи пролунав на зустрічі з В. Януковичем план дій української влади щодо розв’язання проблеми Ю. Тимошенко, К. Більдт відповів: «Ми не хочемо чути планів - ми хочемо бачити результати» ${ }^{22}$.

Тепер розглянемо, як змінювалася того тижня позиція В. Януковича. Як вже зазначалося, раніше він запропонував Пету Коксу та Александру Кваснєвському варіант часткового помилування Юлії Тимошенко. Це питання мала розглядати Комісія при Президентові України у питаннях помилування на засіданні 24 жовтня.

Продовжувалася робота і над варіантом ухвалення закону, який відпустив би Ю. Тимошенко на лікування до берлінської клініки «Charité». 21 жовтня В. Янукович приймав у Києві президента Чехії Мілоша Земана і на спільній прес-конференції з ним роз-

\footnotetext{
${ }^{21}$ Євросоюз закликав Україну докласти додаткових зусиль для асоціації. Дзеркало тижня. 2013. 21 жовтня. URL: $\quad$ https://dt.ua/POLITICS/yevrosoyuz-zaklikav-ukrayinu-doklasti-dodatkovih-zusil-dlya-asociaciyi130458_html

${ }^{22}$ Євросоюзу набрид блеф української влади. Дзеркало тижня. 2013. 22 жовтня. URL: https://dt.ua/POLITICS/yevrosoyuzu-nabrid-blef-ukrayinskoyi-vladi-130508_html
} 
повів, що потрібен окремий закон, який би дозволив засудженим громадянам України, у разі необхідності, мати можливість лікуватися за кордоном. «Такий законопроект зараз розглядається політичними силами в Україні, і найближчим часом його буде внесено на розгляд парламенту», - сказав Янукович ${ }^{23}$.

Між тим 21-22 жовтня в Україні знову перебувала місія П. Кокса та А. Кваснєвського. Вона прагнула переконати опозицію погодитися на умови В. Януковича щодо часткового помилування Ю. Тимошенко. І П. Коксу та А. Кваснєвському це вдалося.

Результатом роботи, проведеної місією у Києві, стала заява голови парламентської фракції партії «Батьківщина» Арсенія Яценюка про те, що інших шляхів, окрім часткового помилування Юлії Тимошенко, немає. «На сьогодні є пропозиція, яку оформлено нашими європейськими партнерами, щодо часткового помилування. Більше пропозицій немає», сказав А. Яценюк. Він зазначив, що шлях вирішення даного питання має бути компромісним. «Це має бути компроміс між урядом України і нашими європейськими партнерами, на який погоджується Юлія Тимошенко», - наголосив він. Тоді ж фракція «Батьківщини» поширила заяву про те, що не подаватиме власних законопроектів про надання засудженим можливості лікуватися за кордоном. «Вирішення проблеми Тимошенко лежить виключно на президентові України Вікторі Януковичі, - говориться у заяві. - До адміністрації президента подано достатню кількість клопотань про звільнення лідера опозиції, зокрема, від голів українських церков, 172 народних депутатів і місії Кокса - Кваснєвського. Потрібна лише політична воля Януковича» ${ }^{24}$.

Народний депутат від «Батьківщини» Олександра Кужель в інтервю радіо «ВВС Україна» повідомила: «Фракція сьогодні зранку ухвалила жорстке рішення, що ми нічого не подаємо. Жодних законопроектів. Бо ми продовжуємо працювати по місії Кокса - Кваснєвського... Наша позиція - це указ про помилування і нічого іншого» ${ }^{25}$.

22 жовтня П. Кокс і А. Кваснєвський побували у Харкові. Дві години вони провели у Центральній клінічній лікарні № 5, де Ю. Тимошенко тоді проходила курс лікування. Вони покинули територію лікарні, як зазвичай, не зупиняючись біля журналістів, які чекали перед входом до лікарні ${ }^{26}$. Результатом цих відвідин стала згода Ю. Тимошенко на часткове помилування на умовах, визначених В. Януковичем.

Наступного дня захисник екс-прем'єра Сергій Власенко заявив, що згода Ю. Тимошенко на часткове помилування не означає, що вона перестане боротися за відновлення своїх громадянських прав. За його словами, запропонований місією П. Кокса А. Кваснєвського варіант часткового помилування $є$ «мінімальним компромісом», який дозволить Ю. Тимошенко «стати вільною людиною». «А з усіма подальшими обтяження-

\footnotetext{
${ }^{23}$ Янукович пообіцяв швидке внесення до Ради законопроекту про лікування засуджених за кордоном. Дзеркало тижня. 2013. 21 жовтня. URL: https://dt.ua/POLITICS/yanukovich-poobicyav-shvidke-vnesennya-do-radizakonoproektu-pro-likuvannya-zasudzhenih-za-kordonom-130429_html

${ }^{24}$ Яценюк вважає єдиним варіантом звільнення Тимошенко часткове помилування. Дзеркало тшжня. 2013. 21 жовтня. URL: https://dt.ua/POLITICS/yacenyuk-vvazhaye-yedinim-variantom-zvilnennya-timoshenkochastkove-pomiluvannya-130417_html

25 «Батьківщина»: жодних проектів, потрібне лише помилування. URL: https://www.bbc.com/ukrainian/mobile/politics/2013/10/131021_tymoshenko_bill_rada_hk.shtml

${ }^{26}$ Кокс і Кваснєвський залишили лікарню Тимошенко без коментарів. Дзеркало тижня. 2013. 22 жовтня. URL: https://dt.ua/POLITICS/koks-i-kvasnyevskiy-zalishili-likarnyu-timoshenko-bez-komentariv-130517_html
} 
ми, які залишаються, ми будемо боротися юридичним шляхом у судових установах України та міжнародних судах», - повідомив С. Власенко. Як він пояснив, додаткове покарання у вигляді втрати права займати посади до трьох років ймовірне, але «це не означає, що Тимошенко і Євросоюз з цим змирилися». Якщо ця частина вироку формально юридично залишиться, Ю. Тимошенко продовжить боротися з цим у міжнародних та європейських інституціях, щоб відстояти своє право брати участь у президентських виборах, розповів С. Власенко $0^{27}$.

Звісно, заява С. Власенка не містила нічого нового для В. Януковича, який, певно, i сам добре розумів, що Ю. Тимошенко не вдовольниться роллю політичної біженки у Німеччині. Але заява С. Власенка важлива для розуміння того, що шанси Ю. Тимошенко позбутися вироку через міжнародні суди виглядали досить високими. Фактично В. Янукович тоді стояв перед вибором: або він здобуває лаври євроінтегратора, який домігся від ЄC підписання Угоди про асоціацію з Україною, i, разом з тим, отримує перспективу поразки на президентських виборах від Ю. Тимошенко - або ж він відмовляється і від звільнення Ю. Тимошенко, і від євроінтеграції.

24 жовтня Комісія при Президентові України у питаннях помилування провела засідання, але питання про помилування Ю. Тимошенко на нього не виносилося. Про це повідомила журналістам член Комісії, перший заступник міністра юстиції Інна Ємельянова. Голова Державної пенітенціарної служби Олександр Лісіцков, теж член Комісії, підтвердив, що ані клопотання місії П. Кокса - А. Кваснєвського, ані інші прохання про помилування екс-прем'єра на засіданні не розглядалися. Члени Комісії відзначили, що наступне їі засідання відбудеться у листопаді, але точна дата поки що невідома ${ }^{28}$.

3 формальної точки зору, нічого особливого тоді не сталося. Просто В. Янукович віддав перевагу іншому варіанту розв'язання проблеми Ю. Тимошенко - через закон про надання засудженим можливості лікуватися за кордоном. Однак насправді цей варіант не був принципово кращим для В. Януковича, бо не давав і не міг дати гарантій відмови Ю. Тимошенко від повернення у політичне життя України.

До того ж цей варіант потребував нового кола узгодження (3 П. Коксом i А. Кваснєвським, з опозицією, з самою Ю. Тимошенко, зрештою з Радою ЄС) і проведення через два читання у Верховній Раді, тоді як варіант часткового помилування можна було здійснити миттєво. Судячи з усього, В. Янукович віддав перевагу варіанту ухвалення закону не для того, щоб його реалізувати, а для того, щоб виграти час для торування собі іншого шляху - в бік РФ. І це вже була не чергова спроба шантажувати ЄС, а свідома відмова від євроінтеграції.

Ще увечері 23 жовтня подібну версію озвучив Арсеній Яценюк в ефірі «5 каналу». «Ми оголошуємо тристоронні переговори: ЄС, опозиція і Юлія Тимошенко, Віктор Янукович. Тільки це має бути не цинічна гра “хто винен”, а робота на результат, яка передбачає звільнення Юлії Тимошенко та підписання Угоди з ЄС», - сказав він. За його словами, як-

\footnotetext{
${ }^{27}$ Власенко підтвердив намір Тимошенко брати участь у президентських виборах. Дзеркало тижня. 2013. 23 жовтня. URL: https://dt.ua/POLITICS/vlasenko-pidtverdiv-namir-timoshenko-brati-uchast-u-prezidentskihviborah-130560_html

${ }^{28}$ Комісія $з$ помилування питання Тимошенко не розглядала. Дзеркало тижня. 2013. 24 жовтня. URL: https://dt.ua/POLITICS/komisiya-z-pomiluvannya-pitannya-timoshenko-ne-rozglyadala-130634_html
} 
що В. Янукович дійсно хоче звільнити Ю. Тимошенко, то «ми можемо прийняти будь-яке рішення у форматі тристоронніх політичних консультацій: Януковича, місії Кокса і Кваснєвського й опозиції. Якщо ми знаходимо цей компроміс, ми вирішуємо це за 24 години». Голова фракції «Батьківщини» нагадав, що Рада ЄC чітко заявила: без звільнення Тимошенко Угоди про асоціацію не буде ${ }^{29}$.

Таким чином, протягом липня-жовтня 2013 р. вкрай загострилися протиріччя навколо підписання Угоди про Асоціацію України та ЄС. Це знайшло вираження у зростанні політичного та економічного тиску РФ з метою запобігти укладанню угоди. Російська сторона вдалася до введення торговельних обмежень для українських виробників і прямих погроз з боку вищого керівництва з метою зірвати підписання угоди. Також посилилися дискусії про необхідність звільнення головного політичного конкурента Віктора Януковича - Юлії Тимошенко. Аналіз діяльності В. Януковича протягом 2013 р. свідчить про його наміри виключити Ю. Тимошенко з президентської кампанії 2015 р. та гарантувати собі обрання на другий строк. Відтак пропозиції про звільнення Ю. Тимошенко - у вигляді декриміналізації статті, за якою їі було засуджено, часткової амністії та надання дозволу на лікування з кордоном - не влаштовували його через відсутність гарантій усунення головної опонентки 3 активного політичного життя на найближчі роки. Навіть поступки з боку опозиції, спрямовані на полегшення процесу підписання Угоди про Асоціацію України та ЄC, не призвели до очікуваних результатів. Тож можна констатувати, що спроби розв'язання протиріч між євроінтеграцією та побудовою авторитарного режиму, здійснені оточенням четвертого українського Президента, зазнали невдачі, що стало однією з передумов Революції Гідності.

\title{
Vadym Denysenko
}

\section{The Acrimony Over the Association Agreement Between the European Union and Ukraine Preparation (July - October 2013)}

\begin{abstract}
The article investigates conflict worsening over the Association Agreement between the European Union and Ukraine. The process of Russian government gradually piling on the economic and diplomatic pressure at Victor Yanukovych to thwart the agreement signature has been described in detail, including the blacklisting of several Ukrainian enterprises by the Russian Customs Office and direct blackmailing on the Russia's highest officials' part. Based on open sources data analysis, the negotiation process between the Ukrainian government and the European Parliament representatives over Julia Tymoshenko's release conditions has been reconstructed, with the key suggestions over the Tymoshenko problem defined, such as partial clemency (statutory reduction, punitive damage payment, loss of civil rights for three years) and medical treatment abroad (legislative amendments to make it possible for the detenu to leave the country in case the medical treatment abroad is necessary). It is stressed

\footnotetext{
${ }^{29}$ «Батьківщина» запропонувала Януковичу та ЄС переговори щодо Тимошенко. Дзеркало тижня. 2013. 24 жовтня. URL: https://dt.ua/POLITICS/batkivschina-zaproponuvala-yanukovichu-ta-yes-peregovori-schodotimoshenko-130591_html.
} 
that Yanukovych personally vouched for the first scenario to keep Tymoshenko away from presidential elections of 2015. However, as reluctant to move on towards Europe as he was due to growing pressure and direct threats from the Russian side, he ended up using the case of the most influential oppositional leader imprisonment as a part of dilatory tactics towards the EUUA agreement signature. The role of European politics, such as Pat Cox, Aleksander Kwaśniewski, Radosław Sikorski and Karl Bildt, in finding the way out of the negotiation crisis, has been highlighted. Julia Tymoshenko and her orbit's position over her release plans has been reflected, i.e., the intention to fight for restoring her civil rights in case of partial clemency or postponing the whole procedure in exchange for UA-EU agreement signature. It is proved that Yanukovych's regime had chosen rapprochement with Russia to avoid defeat at 2015 presidential elections and as a result of constant threats on the Russia's part.

Keywords: Victor Yanukovych, Ukraine-EU association, Julia Tymoshenko, Eurointegration, Pat Cox, Aleksander Kwaśniewski 